\title{
Responses of the spleen to intraamniotic lipopolysaccharide exposure in fetal sheep
}

\author{
Elke Kuypers' ${ }^{1}$, Monique G.M. Willems' ${ }^{1}$, Reint K. Jellema' ${ }^{1}$, Matthew W. Kemp ${ }^{2}$, John P. Newnham², Tammo Delhaas',
} Suhas G. Kallapur ${ }^{2,3}$, Alan H. Jobe ${ }^{2,3}$, Tim G.A.M. Wolfs ${ }^{1}$ and Boris W. Kramer ${ }^{1,2}$

BACKGROUND: Intrauterine inflammation activates the fetal immune system and can result in organ injury and postnatal complications in preterm infants. As the spleen is an important site for peripheral immune activation, we asked how the fetal spleen would respond to intrauterine inflammation over time. We hypothesized that intraamniotic lipopolysaccharide (IA LPS) exposure induces acute and persistent changes in the splenic cytokine profile and T-cell composition that may contribute to the sustained fetal inflammatory response after chorioamnionitis. METHODS: Fetal sheep were exposed to IA LPS 5, 12, and $24 \mathrm{~h}$ and 2, 4, 8, or $15 \mathrm{~d}$ before delivery at $125 \mathrm{~d}$ of gestational age (term $=150 \mathrm{~d}$ ). Splenic cytokine mRNA levels and cleaved caspase-3, CD3, and Foxp3 expression were evaluated.

RESULTS: IA LPS increased interleukin (IL)1, IL4, IL5, and IL10 mRNA by twofold $24 \mathrm{~h}$ after injection. Interferon gamma increased by fivefold, whereas IL23 decreased 15 d post-LPS exposure. Cleaved caspase-3-positive cells increased 2 and $8 \mathrm{~d}$ after LPS exposure. CD3 immunoreactivity increased within $5 \mathrm{~h}$ with increased Foxp3-postive cells at $12 \mathrm{~h}$.

CONCLUSION: Intrauterine inflammation induced a rapid and sustained splenic immune response with persistent changes in the cytokine profile. This altered immune status may drive sustained inflammation and injury in other fetal organs.

들 xposure to intrauterine inflammation is a major risk fac-tor for spontaneous preterm birth and adverse neonatal complications (1). Chorioamnionitis, an often polymicrobial induced inflammation of the chorioamniotic membranes, is present in up to $60 \%$ of all preterm births below $30 \mathrm{wk}$ of gestation (1). Exposure of the fetus to intrauterine inflammation through contact with contaminated amniotic fluid or through the placental-fetal circulation can induce a systemic response referred to as the fetal inflammatory response syndrome (2). Systemic activation of the fetal immune system is associated with multiorgan inflammation and injury, mainly in the lungs, brain, and gut (2). Preterm infants affected by fetal inflammatory response syndrome are subsequently at increased risk for respiratory, neurodevelopmental, and intestinal complications such as bronchopulmonary dysplasia, cerebral white matter injury, and necrotizing enterocolitis, which are conditions associated with tissue inflammation (3).

Activation of the fetal immune system by intrauterine exposure to inflammation is considered to be a key event in the multiorgan consequences following chorioamnionitis. Changes in the balance of inflammatory cells vs. regulatory $\mathrm{T}$ cells, and the Th1/Th2 cytokine profile, result in a proinflammatory shift in the immune response, as demonstrated in experimental models of in utero inflammation and in preterm infants born after chorioamnionitis $(4,5)$. This T-cell-driven sustained immune activation is associated with chronic inflammation and injury in the fetal lungs and gut that might lead to postnatal complications such as bronchopulmonary dysplasia and necrotizing enterocolitis $(6,7)$. Also, shrinkage and lymphocyte depletion of the thymus and spleen have been reported in preterm infants who were exposed to intraamniotic (IA) inflammation $(8,9)$. As the thymus and spleen are two primary organs responsible for T-cell development, function, and activation, changes in their tissue homeostasis or microenvironment can profoundly alter the local and peripheral immune function contributing to adverse neonatal outcomes and enhanced vulnerability for infections postnatally (10-12).

Therefore, we asked how intrauterine inflammation affected the immune cell population and cytokine profile of the fetal spleen, which is an important site for peripheral immune cell activation. As little is known about the dynamics of how the developing fetal immune system is able to respond to an inflammatory stimulus in the amniotic fluid, we aimed to investigate the splenic immune response in a time-related manner thereby capturing both very early and late immunological changes. Fetal sheep were exposed to IA LPS from $5 \mathrm{~h}$ up to $15 \mathrm{~d}$ before preterm delivery. We hypothesized that IA LPS exposure would induce acute and persistent changes in the splenic cytokine profile and T-cell composition, resulting in sustained changes in the immune homeostasis of the fetal spleen.

\section{RESULTS}

\section{Splenic Cytokine mRNA Profile}

The mRNA levels of interleukin (IL) 1 increased about twofold 2,8 , and $15 \mathrm{~d}$ after IA LPS exposure with a transient decrease at $4 \mathrm{~d}$ compared with controls (Figure 1a). IL4 mRNA increased 
by around twofold from $12 \mathrm{~h}$ to $15 \mathrm{~d}$ after LPS administration (Figure 1b). IA exposure to LPS resulted in increased splenic IL5 mRNA levels at early time points followed by reduced levels $4 \mathrm{~d}$ after the injection (Figure 1c). Splenic IL6 (Figure 1d) levels were decreased by $50 \% 4 \mathrm{~d}$ after the LPS injection. IL10 mRNA increased significantly at $24 \mathrm{~h}$ and 2,8 , and $15 \mathrm{~d}$ postLPS exposure and decreased at $4 \mathrm{~d}$ after the exposure compared with controls (Figure 1e). LPS exposure induced splenic IL17 levels at $24 \mathrm{~h}$ and $8 \mathrm{~d}$ (Figure 1f), whereas it reduced IL23 mRNA at 5, 12 and $24 \mathrm{~h}$ and 4 and $15 \mathrm{~d}$ (Figure 1g). Splenic interferon gamma $(I F N \gamma)$ mRNA levels were increased as early as $5 \mathrm{~h}$ after the LPS injection and were elevated up to $15 \mathrm{~d}$ after the exposure (Figure 1h). No differences in splenic IL13 mRNA levels were detected (data not shown).

\section{CD3-Positive T Cells in the Fetal Spleen}

Representative images for the splenic CD3 expression are shown for controls (Figure 2a) and for $5 \mathrm{~h}$ LPS-exposed animals (Figure $2 \mathbf{b}$ ). IA exposure to LPS increased the percentage of CD3-positive stained area in the fetal spleen as early as $5 \mathrm{~h}$ after the injection (Figure 2c). CD3 immunoreactivity increased by twofold 2 and $4 \mathrm{~d}$ after LPS exposure as compared with controls.

\section{Increased Splenic Foxp3-Positive Cells After LPS Exposure}

Representative images of Foxp3-positive cells are shown for controls (Figure 3a) and 12 h LPS-exposed animals (Figure 3b). The number of splenic Foxp3-positive cells per field of view increased at $12 \mathrm{~h}$ after the LPS exposure compared with controls (Figure 3c).

\section{Apoptosis in the Fetal Spleen}

Apoptosis in the fetal spleen was determined by immunohistochemical staining for cleaved caspase-3. Splenic cleaved caspase-3 expression is shown for controls (Figure 4a) and $8 \mathrm{~d}$ LPS-exposed animals (Figure $4 \mathrm{~b}$ ). The number of cleaved a

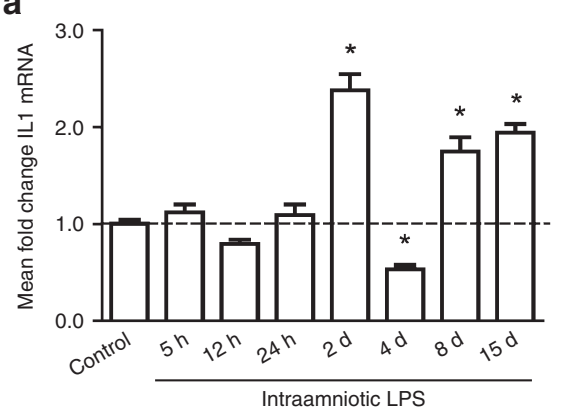

d

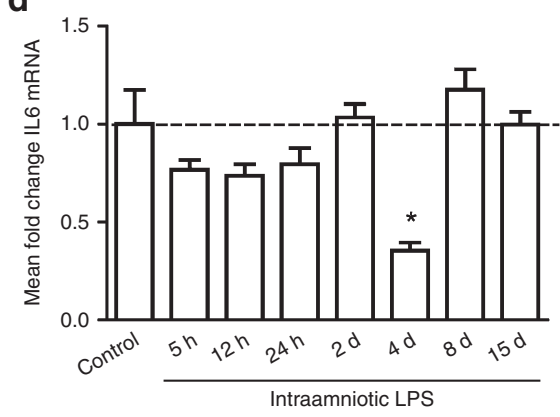

g

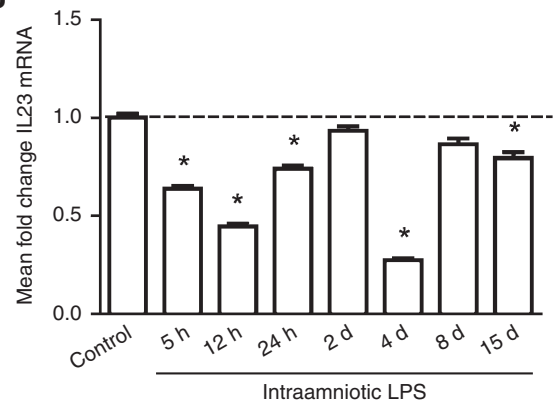

b

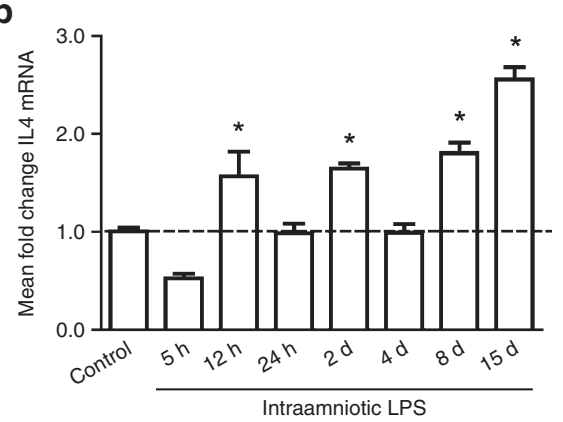

e

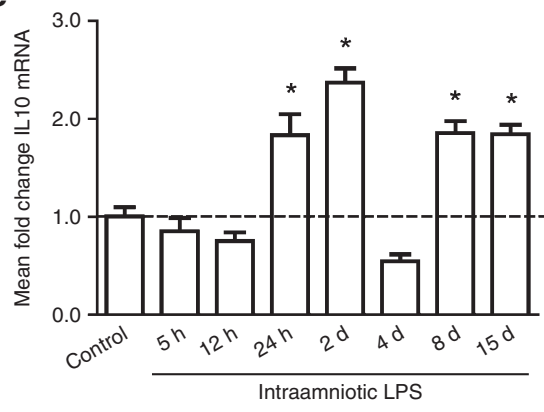

h
C

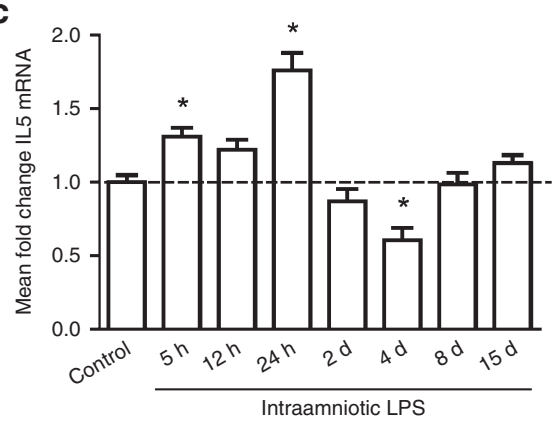

f

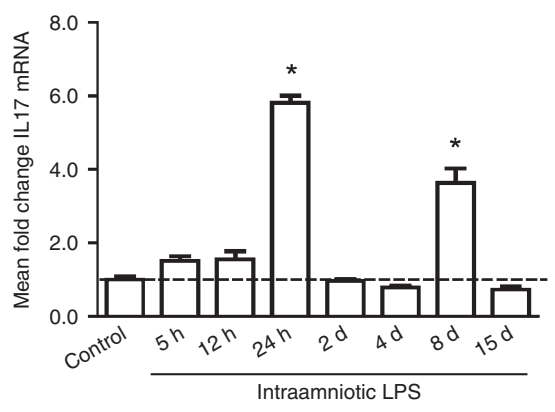

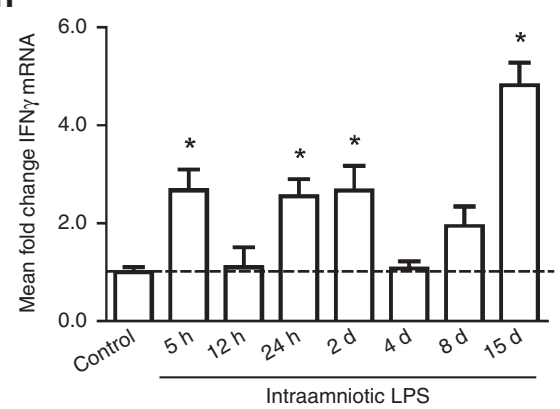

Figure 1. Splenic cytokine mRNA profile. (a) IL1 mRNA levels increased at 2, 8, and $15 \mathrm{~d}$ post-LPS exposure and decreased by $50 \%$ at $4 \mathrm{~d}$ post-LPS exposure. (b) IL4 mRNA increased at $12 \mathrm{~h}$ and 2, 8, and $15 \mathrm{~d}$ after intrauterine LPS exposure. (c) IL 5 mRNA increased at 5 and $24 \mathrm{~h}$ after the LPS injection followed by a decrease at $4 \mathrm{~d}$. (d) IL6 mRNA levels decreased by $60 \% 4 \mathrm{~d}$ after the LPS injection. (e) IL10 mRNA levels were increased after LPS exposure $24 \mathrm{~h}$ and 2, 8, and $15 \mathrm{~d}$ after the injection. (f) IL 17 mRNA increased after exposure to LPS $24 \mathrm{~h}$ and $8 \mathrm{~d}$ before delivery. (g) IL23 mRNA levels decreased in animals exposed to LPS 5, 12, and $24 \mathrm{~h}$ and 4 or $15 \mathrm{~d}$ before delivery. (H) IFN $\gamma$ mRNA levels were increased 5 and $24 \mathrm{~h}$ and 2 and $15 \mathrm{~d}$ after LPS exposure. ${ }^{*} P<0.05$ vs. controls. IFN, interferon; IL, interleukin; LPS, lipopolysaccharide. 
a

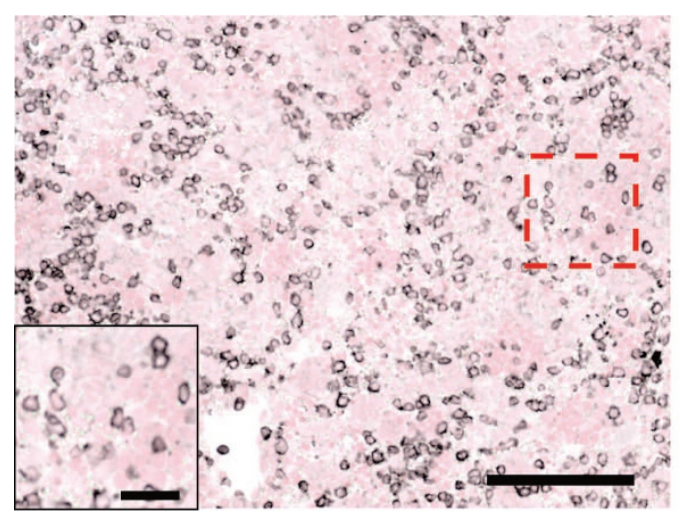

c

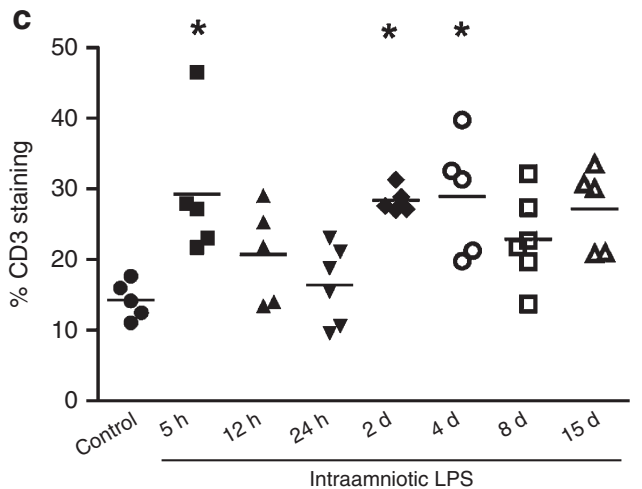

b

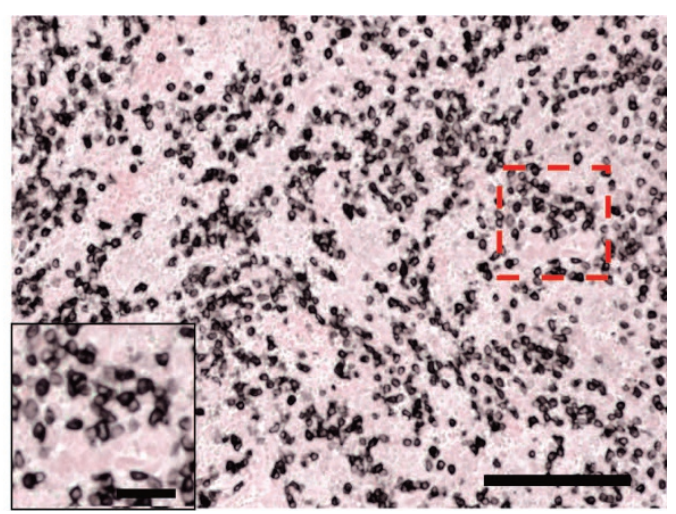




\section{Articles | Kuyperset al.}

a

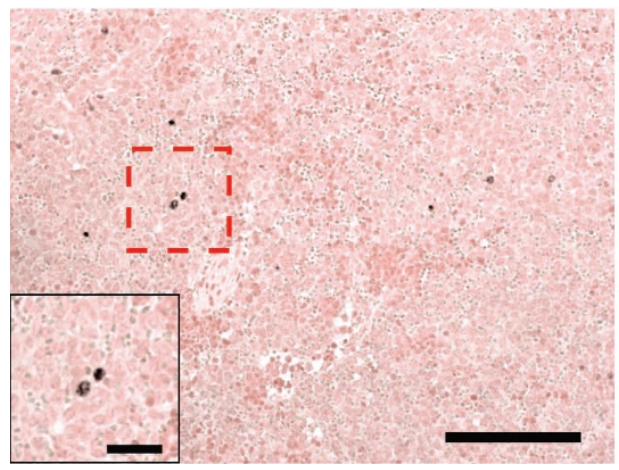

b

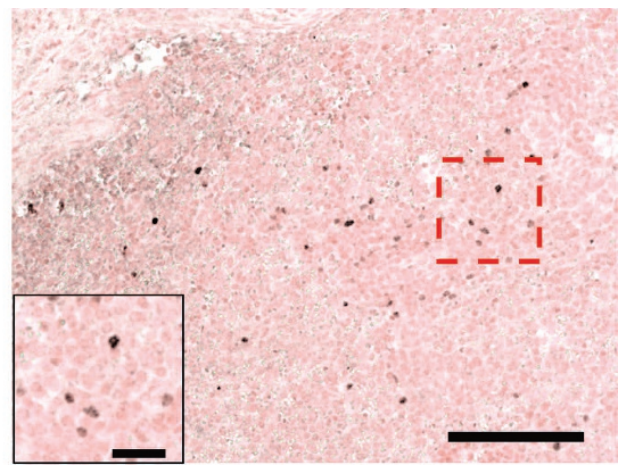

C

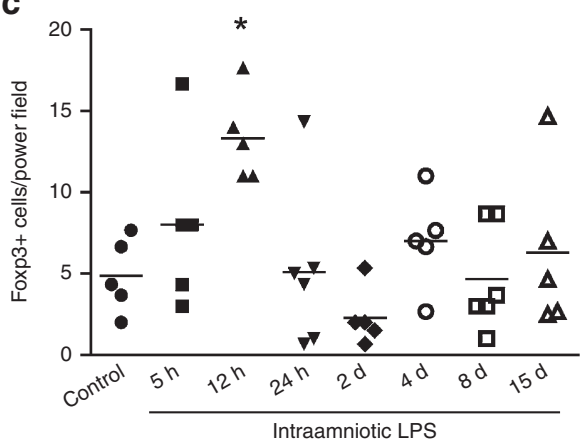

Figure 3. Splenic Foxp3-positive cells. Representative images for Foxp3-positive cells in the spleen are shown for (a) controls and (b) $12 \mathrm{~h} \mathrm{LPS}$-exposed animals. (c) Intraamniotic LPS exposure $12 \mathrm{~h}$ before delivery increased the number of Foxp3-positive cells per power field in the spleen compared with controls. ${ }^{*} P<0.05$ vs. controls. Symbols representing animals in group: $\bullet$, animals control group; $\mathbf{\bullet}, 5 \mathrm{~h}$ LPS group; $\boldsymbol{\Lambda}, 12 \mathrm{~h}$ LPS group; $\boldsymbol{\nabla}, 24 \mathrm{~h}$ LPS group; $\bullet, 2 \mathrm{~d}$ LPS group; $\circ, 4$ d LPS group; $\square, 8$ d LPS group; and $\Delta, 15$ d LPS group. Inset shows Foxp3 expression of redlined area in detail. Bar $=100 \mu \mathrm{m}$; inset $=25 \mu \mathrm{m}$.

a

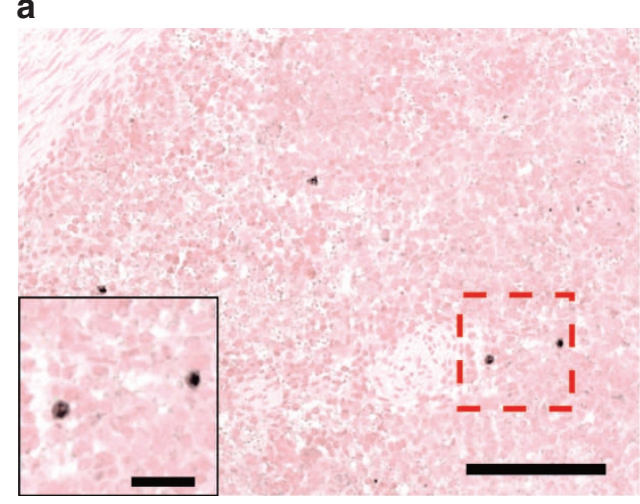

C b

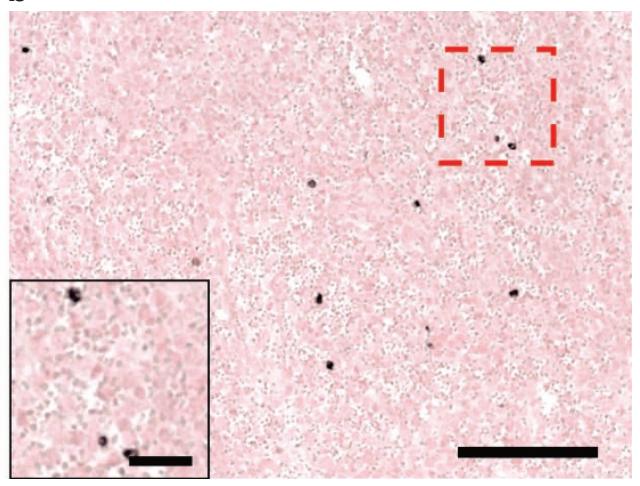

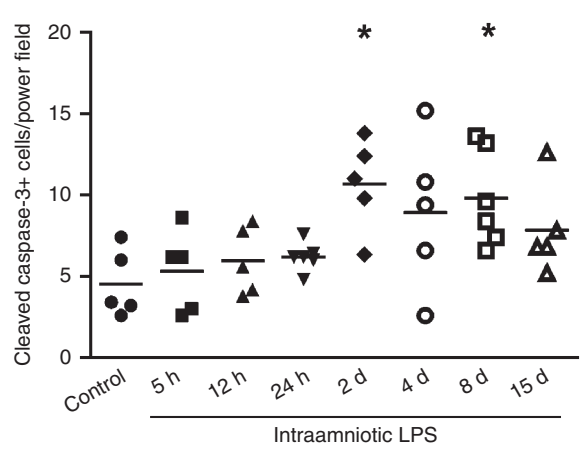

Figure 4. Cleaved caspase-3 expression in the fetal spleen. Representative images for cleaved caspase-3 expression are shown for (a) controls and (b) 8-d LPS-exposed animals. (a) Cleaved caspase-3-positive cells in the fetal spleen increased at 2 and $8 \mathrm{~d}$ after the LPS exposure compared with controls. * $P<0.05$ vs. controls. Symbols representing animals in group: $\bullet$, animals control group; $\mathbf{\bullet} 5 \mathrm{~h}$ LPS group; $\boldsymbol{\Lambda}, 12 \mathrm{~h}$ LPS group; $\boldsymbol{\nabla}, 24 \mathrm{~h}$ LPS group;, $2 \mathrm{~d}$ LPS group; ○, 4 d LPS group; $\square, 8$ d LPS group; and $\Delta, 15$ d LPS group. Inset shows cleaved caspase-3 expression of redlined area in detail. Bar $=100 \mu \mathrm{m}$; inset $=25 \mu \mathrm{m}$. 
Regulatory $\mathrm{T}$ cells are present in the human fetal thymus and spleen from $15 \mathrm{wk}$ of gestation. These regulatory $\mathrm{T}$ cells can inhibit the proliferation of $\mathrm{CD}^{+} \mathrm{T}$ cells in vitro, demonstrating their functionality early in development (24). Upon interaction with the antigen in the spleen, regulatory $\mathrm{T}$ cells migrate from the lymphoid tissue to the site of tissue inflammation to exert their immune suppressive capacities. We speculate that the initial increase in splenic Foxp3-positive cells at $12 \mathrm{~h}$ reflects the transient activation and subsequent migration of regulatory $\mathrm{T}$ cells from the spleen via the systemic circulation to the periphery to regulate the immune response on site, as for example, we detected Foxp3-positive cells in the fetal lungs (25). Furthermore, the fetal spleen mounts complex changes in the cytokine profile following intrauterine LPS administration, both in the early and the late phases. Both Th1 and Th2 cytokines were elevated at $24 \mathrm{~h}$ after LPS administration with upregulation of IFN $\gamma$ as the prominent Th1 cytokine and increased levels of IL4 and IL5 as Th2 cytokines. As these cytokines stimulate the differentiation of $\mathrm{T}$ helper and effector cells, the early increase in CD3 expression in the spleen might be under the influence of these cytokine changes (26).

Decreased levels of splenic IL23 mRNA were prominent in the early phases of immune activation after LPS exposure although IL17 levels increased later on. IL23 is a key to the late stages of differentiation of Th17 cells that are the main producers of IL17 during inflammation (27). Of note, also neutrophils, macrophages, and natural killer cells are known to produce and secrete IL17 especially in the early phases of the immune response (28). This may provide an alternative explanation for the increased levels of IL17 in the fetal spleen without concomitant IL23 induction in this model. Lavoie et al. (29) showed that preterm infants have a severe deficiency in TLR-stimulated IL23 production which may partly explain their increased susceptibility for postnatal infections. The decreased IL23 levels we report in this model may be indicative of the inadequate immune response seen in preterms. After the transient normalization period, we detected a second increase in the cytokine levels, demonstrating the prolonged activation of the immune cells in the fetal spleen. However, characterization of the different $\mathrm{T}$-cell subsets in the fetal spleen will be necessary to gain a better understanding of the complex patterns of cytokine changes in the fetal spleen after intrauterine exposure to inflammation.

Splenic immune responses to IA LPS exposure in this model were detectable up to $15 \mathrm{~d}$. These results are in line with previous findings that IA LPS exposure induces persistent inflammation in the fetal epithelial organs $(1,14,19)$. This sustained tissue inflammation can trigger a systemic inflammatory response in the fetus which further reinforces the inflammatory processes in the periphery. Furthermore, LPS could be detected in the amniotic fluid up to $15 \mathrm{~d}$. This provoked a local production of proinflammatory cytokines by white blood cells that were recruited into the amniotic cavity and placental membranes. This ongoing proinflammatory stimulus subsequently can drive the existing sustained inflammation in the fetus $(13,20,30)$, which is associated with an increased risk for adverse outcomes such as brain damage and pulmonary and intestinal complications $(31,32)$.

In summary, we report that the fetal spleen has complex time-dependent responses following IA inflammation in preterm sheep. There are limitations to this study as we do not have spleen weights and did not characterize the splenocyte subpopulations and various receptor expressions due to lack of appropriate tissue samples and antibodies cross-reacting with sheep. Furthermore, the underlying mechanistic approaches of the inflammatory changes in the fetal spleen or the consequences of these acute changes on the long-term (postnatal) function of the immune system remain to be elucidated. Despite these limitations, we were able to demonstrate that an inflammatory stimulus in the amniotic fluid can elicit complex, dynamic biphasic immunological responses in the developing fetal spleen, which is the major site of peripheral immune activation and regulation. This report contributes to a better understanding of how IA exposure to inflammation can alter the fetal immune response and how this may relate to the multiorgan inflammation and injury following chorioamnionitis in preterm infants.

\section{METHODS}

\section{Experimental Animal Study}

This study was approved by the Animal Ethics Committees at The University of Western Australia and Cincinnati Children's Hospital Medical Center, Ohio, USA. The design of this study was published previously (12). Time-mated Merino ewes with singleton fetuses were randomly allocated to receive an IA injection of $10 \mathrm{mg}$ LPS or $0.9 \%$ saline solution by ultrasound guidance (Escherichia coli 055: B5; Sigma Chemical, St Louis, MO, dissolved in saline) $5 \mathrm{~h}(n=5), 12 \mathrm{~h}$ $(n=5), 24 \mathrm{~h}(n=6), 2 \mathrm{~d}(n=5), 4 \mathrm{~d}(n=5), 8 \mathrm{~d}(n=6)$, or $15 \mathrm{~d}(n=$ 5) before preterm delivery at $125 \mathrm{~d}$ of gestational age (term $=150 \mathrm{~d}$ of gestational age) which corresponds to $28-32 \mathrm{wk}$ in humans. No differences were observed between control animals that received saline injections at different time points before delivery, and the control animals were therefore combined in one group $(n=5)$. The preterm lambs were killed after surgical delivery. Splenic tissue was removed and snap-frozen or fixed in 10\% buffered formalin for $24 \mathrm{~h}$.

\section{RNA Extraction and Quantitative Real-Time PCR}

The mRNA levels of cytokines from the innate immune system (IL1 and IL6), adaptive T-helper (Th)1 (IFN $\gamma$ ), Th2 (IL4, IL5, IL10, IL13) and Th17 (IL17, IL23) system were measured by quantitative realtime PCR as described previously (12). Total RNA was extracted from snap-frozen splenic tissue with Trizol/chloroform. Genomic DNA contamination was removed by treatment with RQ1 DNase (M610A, Promega), and the RNA was tested for the presence of genomic DNA. Briefly, PCR amplification for the detection of genomic DNA was performed with DNA Taq Polymerase (M124B, Promega) at $95^{\circ} \mathrm{C}$ for 5 min followed by 40 cycles at $95^{\circ} \mathrm{C}$ for $30 \mathrm{~s}, 55^{\circ} \mathrm{C}$ for $45 \mathrm{~s}$, and 72 ${ }^{\circ} \mathrm{C}$ for $30 \mathrm{~s}$. Total RNA was used as a template. The PCR products and RNA integrity were analyzed on a $1.5 \%$ agarose gel. Total RNA was converted to cDNA with the Transcription First Strand cDNA synthesis kit (Roche-Applied, Mannheim, Germany). Quantitative real-time PCR reactions were performed with $5 \mu \mathrm{l}$ of cDNA in duplicate with the LightCycler 480 SYBR Green I Master mix (Roche-Applied) on a LightCycler 480 Instrument. Primer sequences are listed in Table 1. Mean fold changes in mRNA expression compared with the control group were calculated by the ${ }^{\Delta \Delta} C_{t}$ method after normalization to the housekeeping gene ovine 40S ribosomal protein S15 (ovRPS15) (33).

\section{Immunohistochemistry}

Paraffin-embedded splenic sections ( $4 \mu \mathrm{m}$, transverse) were immunostained for CD3 (marker for effector T cells, A0452; DAKO, 
Table 1. Primers used for RT-PCR

\begin{tabular}{|c|c|c|c|}
\hline Gene & & Sequence $\left(5^{\prime}-3^{\prime}\right)$ & $\begin{array}{c}\text { Temperature } \\
\left({ }^{\circ} \mathrm{C}\right)\end{array}$ \\
\hline \multirow[t]{2}{*}{ IL1 } & Fw & CACTGCCAGAAAATAAGCTGAAAC & 63 \\
\hline & $\mathrm{Rv}$ & TGATCAAGCAAATCGCCTGAT & \\
\hline \multirow[t]{2}{*}{ IL4 } & Fw & TGCCTGTAGCAGACGTCTTTG & 66 \\
\hline & $\mathrm{Rv}$ & GCCCTGCAGAAGGTTTCCT & \\
\hline \multirow[t]{2}{*}{ IL5 } & Fw & GCATCTGCGTTTGACCTTGG & 60 \\
\hline & $\mathrm{Rv}$ & AGTTTGATGCGTGGAGAGCA & \\
\hline \multirow[t]{2}{*}{ IL6 } & Fw & ACATCGTCGACAAAATCTCTGCAA & 65 \\
\hline & $\mathrm{Rv}$ & GCCAGTGTCTCCTTGCTGTTT & \\
\hline \multirow[t]{2}{*}{ IL10 } & Fw & CATGGGCCTGACATCAAGGA & 64 \\
\hline & $\mathrm{Rv}$ & CGGAGGGTCTTCAGCTTCTC & \\
\hline \multirow[t]{2}{*}{ IL13 } & Fw & AGGAGGGACTGTTACTGCCA & 60 \\
\hline & $\mathrm{Rv}$ & CCCACTGCTTTAGTGCTGGA & \\
\hline \multirow[t]{2}{*}{ IL17 } & Fw & TGTGAGGGTCAACCTGAACAT & 62 \\
\hline & $\mathrm{Rv}$ & TGATAATCGGTGGGCCTTCTG & \\
\hline \multirow[t]{2}{*}{ IL23 } & Fw & GGGAAGTGGACAGAGGTTCC & 60 \\
\hline & $\mathrm{Rv}$ & CTGCCTCTCCAATCTGGCTG & \\
\hline \multirow[t]{2}{*}{$\mathrm{IFN} \gamma$} & Fw & TCAAGCAAGACATGTTTCAGAAGTTCT & 60 \\
\hline & $\mathrm{Rv}$ & CCGGAATTTGAATCAGCCTTTTTGAA & \\
\hline \multirow[t]{2}{*}{ ovRPS15 } & Fw & CGAGATGGTGGGCAGCAT & 60 \\
\hline & $\mathrm{Rv}$ & GCTTGATTTCCACCTGGTTGA & \\
\hline
\end{tabular}

FW, forward; IFN, interferon; RT-PCR, real-time PCR; RV, reverse.

Glostrup, Denmark), Foxp3 (marker for regulatory T cells, 14-7979; eBiosciences, San Diego, CA) and cleaved caspase-3 (cellular apoptosis marker, Asp175, \#9661S; Cell Signaling Technology, Boston, MA) as reported elsewhere (12). The sections were evaluated by light microscopy (Axioskop 40; Zeiss, Oberkochen, Germany) with LeicaQWin Pro v.3.4.0 software (Leica Microsystems, Wetzlar, Germany). Five representative images were taken at $\times 200$ magnification. For CD3, the percentage of positively stained area was measured in five representative images at $\times 200$ magnification by applying a standardized threshold using Image J software, and the results were averaged per animal (Rasband, W.S.; Image J US National Institutes of Health, Bethesda, MS). Foxp3-positive and cleaved caspase-3-positive cells were counted for five representative images at $\times 200$ magnification and averaged per animal. All analyses were performed in a blinded manner by a single observer.

\section{Data Analysis}

RT-PCR data is shown as means \pm SEM. LPS-exposed groups were compared with the control group using one-way ANOVA with Dunnett's for post hoc analysis or by a nonparametric Kruskal-Wallis test with Dunn's for post hoc analysis as appropriate. Statistical analysis was performed by GraphPad Prism v5.0 (GraphPad Prism, La Jolla, CA). Significance was accepted at $P<0.05$.

\section{ACKNOWLEDGMENTS}

We thank Richard Stolle, Masatoshi Saito, Shaofu Li, Jennifer Henderson, Nico Kloosterboer, Leon Janssen, and Dennis Kruk for excellent technical support.

\section{STATEMENT OF FINANCIAL SUPPORT}

This study was supported by NIH HD-57869 (S.G.K.) from the National Institutes of Health (NIH; Bethesda, MD, USA), the National Health and Medical Research Council of Australia, the Women and Infants Research Foundation, Western Australia, Veni BWK 016.096.141 from the Dutch Scientific Research Organization, and the Research School for Oncology and Developmental Biology (GROW), Maastricht University. The funders had no role in study design, data collection and analysis, decision to publish, or preparation of the manuscript.

Disclosure: None of the authors have a conflict of interest.

\section{REFERENCES}

1. Goldenberg RL, Hauth JC, Andrews WW. Intrauterine infection and preterm delivery. N Engl J Med 2000;342:1500-7.

2. Gotsch F, Romero R, Kusanovic JP, et al. The fetal inflammatory response syndrome. Clin Obstet Gynecol 2007;50:652-83.

3. Gantert M, Been JV, Gavilanes AW, Garnier Y, Zimmermann LJ, Kramer BW. Chorioamnionitis: a multiorgan disease of the fetus? J Perinatol 2010;30:Suppl:S21-30.

4. Kallapur SG, Presicce P, Senthamaraikannan P, et al. Intra-amniotic IL-1 $\beta$ induces fetal inflammation in rhesus monkeys and alters the regulatory T cell/IL-17 balance. J Immunol 2013;191:1102-9.

5. Varvarigou AA, Thomas I, Rodi M, Economou I, Mantagos S, Mouzaki A. Respiratory distress syndrome (RDS) in premature infants is underscored by the magnitude of Th1 cytokine polarization. Cytokine 2012;58:355-60.

6. Rosen D, Lee JH, Cuttitta F, Rafiqi F, Degan S, Sunday ME. Accelerated thymic maturation and autoreactive $\mathrm{T}$ cells in bronchopulmonary dysplasia. Am J Respir Crit Care Med 2006;174:75-83.

7. Nanthakumar N, Meng D, Goldstein AM, et al. The mechanism of excessive intestinal inflammation in necrotizing enterocolitis: an immature innate immune response. PLoS One 2011;6:e17776.

8. Toti P, De Felice C, Occhini R, et al. Spleen depletion in neonatal sepsis and chorioamnionitis. Am J Clin Pathol 2004;122:765-71.

9. De Felice C, Toti P, Santopietro R, Stumpo M, Pecciarini L, Bagnoli F. Small thymus in very low birth weight infants born to mothers with subclinical chorioamnionitis. J Pediatr 1999;135:384-6.

10. De Felice C, Latini G, Del Vecchio A, Toti P, Bagnoli F, Petraglia F. Small thymus at birth: a predictive radiographic sign of bronchopulmonary dysplasia. Pediatrics 2002;110(2 Pt 1):386-8.

11. Kuban JD, Allred EN, Leviton A. Thymus involution and cerebral white matter damage in extremely low gestational age neonates. Biol Neonate 2006;90:252-7.

12. Kuypers E, Wolfs TG, Collins JJ, et al. Intraamniotic lipopolysaccharide exposure changes cell populations and structure of the ovine fetal thymus. Reprod Sci 2013;20:946-56.

13. Kallapur SG, Willet KE, Jobe AH, Ikegami M, Bachurski CJ. Intra-amniotic endotoxin: chorioamnionitis precedes lung maturation in preterm lambs. Am J Physiol Lung Cell Mol Physiol 2001;280:L527-36.

14. Wolfs TG, Buurman WA, Zoer B, et al. Endotoxin induced chorioamnionitis prevents intestinal development during gestation in fetal sheep. PLoS One 2009;4:e5837.

15. Bieghs V, Vlassaks E, Custers A, et al. Chorioamnionitis induced hepatic inflammation and disturbed lipid metabolism in fetal sheep. Pediatr Res 2010;68:466-72.

16. Kuypers E, Jellema RK, Ophelders DR, et al. Effects of intra-amniotic lipopolysaccharide and maternal betamethasone on brain inflammation in fetal sheep. PLoS One 2013;8:e81644.

17. Collins JJ, Kuypers E, Nitsos I, et al. LPS-induced chorioamnionitis and antenatal corticosteroids modulate Shh signaling in the ovine fetal lung. Am J Physiol Lung Cell Mol Physiol 2012;303:L778-87.

18. Wolfs TG, Kallapur SG, Knox CL, et al. Antenatal ureaplasma infection impairs development of the fetal ovine gut in an IL-1-dependent manner. Mucosal Immunol 2013;6:547-56.

19. Kallapur SG, Jobe AH, Ball MK, et al. Pulmonary and systemic endotoxin tolerance in preterm fetal sheep exposed to chorioamnionitis. J Immunol 2007;179:8491-9.

20. Zhang L, Saito M, Jobe A, et al. Intra-amniotic administration of E coli lipopolysaccharides causes sustained inflammation of the fetal skin in sheep. Reprod Sci 2012;19:1181-9.

21. Wolfs TG, Kallapur SG, Polglase GR, et al. IL-1 $\alpha$ mediated chorioamnionitis induces depletion of FoxP3 + cells and ileal inflammation in the ovine fetal gut. PLoS One 2011;6:e18355.

22. Villadangos JA, Heath WR. Life cycle, migration and antigen presenting functions of spleen and lymph node dendritic cells: limitations of the Langerhans cells paradigm. Semin Immunol 2005;17:262-72. 
23. Sun YL, Lin GG, Zhang K, Wang LN, Li JM. Application and effects of mouse Foxp3 antibody and fixation/permeabilization buffer on the detection of CD4+ regulatory $\mathrm{T}$ cells in various mammal species. Genet Mol Res 2013;12:6535-45.

24. Cupedo T, Nagasawa M, Weijer K, Blom B, Spits H. Development and activation of regulatory $\mathrm{T}$ cells in the human fetus. Eur J Immunol 2005;35:383-90.

25. Kuypers E, Collins JJ, Kramer BW, et al. Intra-amniotic LPS and antenatal betamethasone: inflammation and maturation in preterm lamb lungs. Am J Physiol Lung Cell Mol Physiol 2012;302:L380-9.

26. Reed JM, Branigan PJ, Bamezai A. Interferon gamma enhances clonal expansion and survival of CD4+ T cells. J Interferon Cytokine Res 2008;28:611-22.

27. Tan ZY, Bealgey KW, Fang Y, Gong YM, Bao S. Interleukin-23: immunological roles and clinical implications. Int J Biochem Cell Biol 2009;41:733-5.

28. Korn T, Bettelli E, Oukka M, Kuchroo VK. IL-17 and Th17 Cells. Annu Rev Immunol 2009;27:485-517.
29. Lavoie PM, Huang Q, Jolette E, et al. Profound lack of interleukin (IL)-12/ IL-23p40 in neonates born early in gestation is associated with an increased risk of sepsis. J Infect Dis 2010;202:1754-63.

30. Newnham JP, Kallapur SG, Kramer BW, et al. Betamethasone effects on chorioamnionitis induced by intra-amniotic endotoxin in sheep. Am J Obstet Gynecol 2003;189:1458-66.

31. Leviton A, Kuban K, O'Shea TM, et al. The relationship between early concentrations of 25 blood proteins and cerebral white matter injury in preterm newborns: the ELGAN study. J Pediatr 2011;158:897-903. e1-5.

32. Been JV, Lievense S, Zimmermann LJ, Kramer BW, Wolfs TG. Chorioamnionitis as a risk factor for necrotizing enterocolitis: a systematic review and meta-analysis. J Pediatr 2013;162:236-42 e2.

33. Livak KJ, Schmittgen TD. Analysis of relative gene expression data using real-time quantitative PCR and the 2(-Delta Delta C(T)) Method. Methods $2001 ; 25: 402-8$. 